\title{
Cyfrowy uczeń - analogowa szkoła? Dylematy procesu kształcenia w przestrzeni medialnej
}

\section{KEYWORDS}

network generation, digital technologies, technological immersion, teaching of the digital era

\begin{abstract}
Borawska-Kalbarczyk Katarzyna, Cyfrowy uczeń - analogowa szkoła? Dylematy procesu kształcenia w przestrzeni medialnej [Digital student - analogue school? Dilemmas of the educational process in the media space]. Kultura Społeczeństwo - Edukacja nr 2(14) 2018, Poznań 2018, pp. 39-50, Adam Mickiewicz University Press. ISSN 23000422. DOI 10.14746/kse.2018.14.3.
\end{abstract}

\begin{abstract}
The article assesses the quality of the educational process carried out in the dimension of the use of new media. The author argues that the modern school still uses too many analog methods, offering education not adapted to the expectations of students who are part of the digital native generation. Theoretical analysis is supplemented by the results of studies from national and international reports on the level of teachers' media competence. The text proposes solutions that reinforce the idea of digital teaching and some of the benefits resulting from its implementation.
\end{abstract}

\section{Wprowadzenie - cyfrowy wymiar rzeczywistości}

Dominujące we współczesnym świecie technologie informacyjne mają niezaprzeczalnie znaczący wpływ na przemiany niemal wszystkich sfer naszego życia. Wciąż udoskonalane techniki generowania, transformowania i dystrybuowania informacji, a co za tym idzie - sterowania procesami produkcyjnymi, badaniami naukowymi, zarządzaniem, procesem kształcenia i wieloma innymi obszarami ludzkiej aktywności, przyczyniają się do stałego rozwoju społeczeństwa informacyjnego. 
Nowa era w dziedzinie komunikowania się, pracy, edukacji, rozrywki, gospodarki i innych płaszczyzn istnienia człowieka rozpoczęła się wraz z rozpowszechnieniem się Internetu. Jak zauważają Alexander Bard i Jan Söderqvist

Internet jest czymś zupełnie nowym - to medium, w którym każdy, wydając stosunkowo niewielką kwotę na środki techniczne i wykonując kilka prostych czynności, może stać się zarówno producentem, jak i konsumentem tekstu, obrazu i dźwięku. Trudno wyobrazić sobie coś bardziej inspirującego - w sieci wszyscy jesteśmy autorami, wydawcami i producentami, nasza wolność ekspresji nie ma ograniczeń, a potencjalna widownia jest nieograniczona. Oceany wszystkich możliwych informacji dostępne są za pomocą jednego kliknięcia myszy. Rozwoju tego nowego medium nie da się porównać z niczym innym. (Bard, Söderqvist, 2008: 35)

Dla członków społeczeństwa informacyjnego komputer, Internet i wszelkie techniki cyfrowe stają się niezmiernie ważnymi aspektami życia i pracy. Świat nowych mediów (Lister, Dovey, Giddings, Grant, Kelly, 2009) tworzy odmienną od znanej dotychczas rzeczywistość społeczną, w której kontakty między ludźmi odbywają się za pośrednictwem mediów tworzących swoistą przestrzeń wirtualną i medialną kulturę; infrastruktura medialna jest fundamentem obiegu informacyjnego o różnym nasileniu i zasięgu we wszystkich sferach życia, a wszelkie ludzkie działania są wspomagane przez formy medialno-teleinformacyjne (Goban-Klas, 2005: 106). Należy uznać, że Internet swoim zakresem, rozmiarami i charakterem przekroczył ramy wszelkich dotychczasowych systemów informacyjnych i nadal się rozwija w sposób dynamiczny. Co więcej, jego ważną cechą jest swego rodzaju „oddolny” rozwój i kształtowanie się niekontrolowane, czy wręcz spontaniczne. Derrick de Kerckhove twierdzi, że stanowi on coś w rodzaju podświadomej zbiorowej inteligencji, co może wynikać z tego, że jego użytkownikami nie są jedynie bierni konsumenci informacji, ale i jej aktywni prosumenci (Kerckhove, 1996: 68, 72).

Tonino Catelmi, włoski badacz uzależnień od Internetu i wpływu technologii na ludzki umysł, na określenie obserwowanych zjawisk współczesnej rzeczywistości medialnej używa pojęcia „technopłynność”.

Technopłynne społeczeństwo to społeczeństwo cały czas aktywne, „nieustannie w ruchu”, które traci zdolność wyłączenia się. (...) Technopłynne społeczeństwo jest przede wszystkim społeczeństwem, które zniosło sztywne granice. Cyfrowy świat przyciąga, rozrasta się w niepohamowany sposób, wywołuje entuzjazm i ekscytację. (Catelmi, 2015: 31-32)

Członkowie technopłynnej rzeczywistości stoją w obliczu wielorakich wyzwań, którym muszą sprostać - można tu zasygnalizować niepokojące zjawiska zorientowane wokół tak zwanej kultury teraźniejszości, przemian temporalnych, 
informacyjnego nadmiaru i nieumiejętności konsumpcji informacji oraz procesu neuronalnych przeobrażeń młodych umysłów zanurzonych w sieć. W kulturze teraźniejszości unika się kontynuacji, zakotwiczenia, zachowania tradycji, wytyczania perspektywy celów dalekosiężnych, dominuje maksymalizowanie chwili obecnej, z naciskiem na indywidualne przyjemne doznania (Gleick, 2003; Gleick, 2012; Ledzińska, 2009; Szlendak, 2009; Eriksen, 2003; Krauze-Sikorska, Klichowski, 2013). Rewolucja cyfrowa, której jesteśmy obserwatorami i aktorami, uruchamia nowe wymiary poznawania rzeczywistości, kształtuje nową kulturę i zupełnie odmienne od poprzednich sposoby doświadczania relacji ze światem, innymi i sobą samym. Przeobrażenia dotykające współczesną cywilizację zmuszają do przewartościowania wielu systemów zachowań, schematów myślenia, kształtowania umiejętności i postaw. Jednym z istotnych obszarów dotkniętych koniecznością gruntownego przekształcenia dotychczasowych algorytmów działań jest sfera edukacji. Nowe kulturowo media, jakimi są Internet i związane z nim technologie cyfrowe, skłaniają osoby zainteresowane jakością procesu kształcenia do podjęcia dyskursu na temat sposobów funkcjonowania szkoły w odmiennych od wcześniejszych lat warunkach.

Celem niniejszego artykułu jest odpowiedź na pytanie, w jakim stopniu model kształcenia, oferowany przez współczesną szkołę, wychodzi naprzeciw zmieniającym się warunkom życia w stechnologizowanym świecie, a przede wszystkim w jakim stopniu edukacja jest w stanie sprostać oczekiwaniom jej najważniejszych (i wymagających adresatów) - uczniów pokolenia sieci.

\section{Pokolenie sieci w szkolnej ławce}

Dzisiejsi uczniowie wszystkich szczebli kształcenia, wraz ze studentami, należą do pokolenia wychowanego w obecności mediów cyfrowych, kształtujących ich styl życia i silnie determinujących sposób poznawania świata oraz uczenie się. Pokolenie, zwane już powszechnie digital natives, żyje w sieci, czerpie wiele $\mathrm{z}$ zasobów Internetu, prowadzi w mediach społecznościowych równoległe życie. Będąc w permanentnym kontakcie z innymi członkami swojej społeczności, dzięki mobilnym urządzeniom staje się pokoleniem „wireless” (bezprzewodowym) (Hejwosz-Gromkowska, 2015: 180), zanurzonym w wyimaginowanym, wygenerowanym przez technologię 3D świecie wirtualnym. Michał Ostrowicki, opisując zjawisko intensywnego zanurzenia jednostki w cyberprzestrzeń, posługuje się pojęciem immersja, którą definiuje jako „proces wciągania, pochłaniania lub zanurzenia człowieka w środowisku elektronicznym, w wyniku czego aktywizuje on 
tam działanie, przy czym mamy na myśli głównie zaangażowanie duchowe, np. emocjonalno-uczuciowe" (Ostrowicki, 2007: 539-540). Immersja w świat cyfrowy młodych ludzi z pokolenia $C$ kreuje ich określony wizerunek, także cyfrowy, na który składają się ślady odciśnięte przez ich własną, codzienną bytność w sieci, jak również efekty narcystycznej i ekshibicjonistycznych skłonności własnej (i rodziców), realizowanych w ramach stylizowania własnej facebookowej tożsamości (Melosik, 2013; Szpunar, 2016). Antoni Zając formułuje w tym kontekście tezę, iż „człowiek stworzył technologię cyfrową, ta wytworzyła kulturę, z kolei technologia i kultura tworzą nowego człowieka" (Zając, 2011: 113). Pokolenie sieci ma zupełnie odmienne nawyki medialne niż ich rodzice w tym samym wieku - dominacja pasywnego odbioru przekazu telewizyjnego i radiowego ustąpiła miejsca aktywnemu użytkowaniu wirtualnej cyberprzestrzeni. Przeciętny polski nastolatek prawie 20 godzin tygodniowo jest online - dwukrotnie dłużej niż pokolenie rodziców i ponadtrzykrotnie dłużej niż pokolenie dziadków.

Czas, jaki przeznaczamy na użytkowanie różnych rodzajów mediów, powiększa się nieustannie. W świetle przeprowadzanych cyklicznie badań, dostępnych na portalu We Are Social (raport „Mobile i digital w Polsce i na świecie w 2016 r.”) średni dzienny czas, jaki Polacy, bez podziału na grupy wiekowe, spędzają, korzystając z poszczególnych mediów, przedstawia się następująco: 4 godz. 25 min - Internet (komputer lub tablet); 1 godz. 17 min - Internet mobilny i smartfon; 1 godz. 17 min - sieci społecznościowe na różnych urządzeniach; 2 godz. 28 min - czas spędzany podczas oglądania telewizji (dok. elektr. Digital in 2016, 2016).

Technologie przenikające codzienność młodych

zapośredniczają bycie razem oraz bycie sobą. W tym sensie wpisują się w formowanie własnej tożsamości. Są przez młodych wykorzystywane do odnajdowania się i oznaczania odnalezionego miejsca w świecie. W ten sposób stają się oni wobec siebie samych przedmiotami zarządzania, planowania, selekcjonowania, tworzenia. (Filiciak, Danielewicz, Halawa, Mazurek, Nowotny, 2010: 65)

Wygenerowana przez zasoby technologiczne przestrzeń wirtualna jest dla młodych ludzi tak samo istotna (a może bardziej) jak realna. Świat, w którym mieszkają, kontaktują się z innymi, bawią się czy uczą, będący połączeniem dwóch wymiarów: realnego i wirtualnego, zatem trudno im jest wyobrazić sobie rzeczywistość skurczoną do jednego z nich - realnie namacalnego (Jaskuła, 2015).

W opisie stylu funkcjonowania pokolenia sieci zwraca uwagę niesłabnące poczucie trudności wyobrażenia sobie życia bez dostępu do Internetu oraz większe umiejętności i wiedza młodzieży w zakresie użytkowania nowych mediów od pokolenia rodziców. Ta ostatnia cecha kieruje uwagę na przynależność współ- 
czesnej młodzieży do pokolenia prefiguratywnego, używając określenia Margaret Mead (Mead, 2000). Prowadzi to do podziału, zwerbalizowanego przez Marka Prensky'ego, na cyfrowych tubylców, prowadzących w świecie wirtualnym równoległe życie, i cyfrowych imigrantów, traktujących nowe media $\mathrm{z}$ dystansem lub wręcz bojaźnią (Prensky, 2012). Badacz dostrzegł, że zmiany pokoleniowe, zaistniałe na skutek oddziaływania technologii cyfrowej, mogą stanowić poważną barierę utrudniającą skuteczne porozumienie między wymienionymi pokoleniami. Rozziew ten, zaobserwowany w stratyfikacji społeczno-kulturowej autora, rzutuje także na funkcjonowanie ucznia i nauczyciela w przestrzeni edukacyjnej. Blokada porozumienia międzypokoleniowego rozciąga się zatem na sferę edukacji.

Wypracowane dotychczas metody kształcenia okazują się nie do końca wystarczająco skuteczne w odniesieniu do pokolenia cyfrowych tubylców. Trafnie podkreśla to Tomasz Goban-Klas, zauważając, iż „W nowej sytuacji znalazła się też szkoła, ponieważ narodził się nowy uczeń: «medialny i mobilny»" (Goban-Klas, 2002: 45). Współczesna przestrzeń informacyjna, w której zanurzony jest uczeń, wymaga nowego podejścia do kształcenia i wychowania: winno ono czerpać inspiracje $\mathrm{z}$ możliwości oferowanych przez świat cyfrowych technologii.

\section{Szkoła w wymiarze analogowym}

Obserwując i analizując dydaktyczną działalność szkoły w kontekście unowocześnienia procesu kształcenia i wyjścia naprzeciw oczekiwaniom młodego pokolenia, należy, niestety, zauważyć, że należy ona do najbardziej konserwatywnych instytucji społecznych. „Wolno reaguje na zmiany zachodzące w otaczającej nas rzeczywistości, ignoruje fakt, że dzisiejszy uczeń pochodzi z innego, cyfrowego świata” (Morbitzer, 2010). Wielokrotnie nie sposób ulec wrażeniu, że świat digital natives (uczniowie) i edukacyjna przestrzeń kreowana przez digital immigrants (nauczyciele) to dwie odrębne płaszczyzny, określane przez diametralnie odmienne zestawy celów, motywy działania czy środki realizacji. Mariusz Przybyła w próbie odpowiedzi na to pytanie sprowadza obraz szkoły do wizji „zachowawczego żandarma, który na wszelki wypadek próbuje «zamknąć Internet», ograniczyć dostęp do innowacyjnych rozwiązań” (Przybyła, 2012: 205). Edukatorzy i nauczyciele deklarujący idee wzmacniania indywidualnego podejścia do ucznia, kształtowania jego pasji i zainteresowań, zamykając się na możliwości edukacyjne cyfrowych technologii, zaprzeczają samym sobie, przyczyniając się do wzmocnienia analogowego wizerunku szkoły. Paradoksalnie, najnowsze technologie w szkole pojawiły się masowo w... regulaminach i statutach, w dziale... „zabrania się używania”. Zakaz używania telefonów 
komórkowych, fotografowania, filmowania i nagrywania zajęć jest powszechny. Za wyznacznik nowoczesności uchodzą tablice interaktywne, chociaż, jak dowodzi Lechosław Hojnacki, nie są same w sobie żadną innowacją, że już raczej pomagają konserwować tradycyjną dydaktykę (wyświetlanie prezentacji, zastępowanie rzutnika) (Hojnacki, 2013: 43). Unikanie włączenia nowych technologii we wszystkie płaszczyzny procesu kształcenia wzmacnia istniejącą w szkołach kulturę pozoru, dotykającą omawianą tu perspektywę dydaktyki cyfrowej. Trening zakorzeniania uczniów w kulturze pozoru wzmacnianej nieadekwatnością kulturową szkoły (Klus-Stańska, 2005) uniemożliwia przełamanie dysonansu między wielowymiarowym zaangażowaniem uczniów w nurt oddziaływań medialnych a jednostronnym, tradycyjnym przekazem treści edukacyjnych i tym samym wzmacnia indolencję szkoły na płaszczyźnie realizacji celów edukacji medialnej. Eliminowanie nowych mediów ze szkoły lub ich ignorowanie równoznaczne jest ze swoistym odcięciem się od uczniów oraz od elementu ich codzienności. Realizacja procesu kształcenia z pominięciem wykorzystania nowoczesnych mediów ma niewielki związek z tym, co uczeń robi poza szkołą i w domu. Immersja w świat mediów cyfrowych sprawiła, że uczeń odczuwa w efekcie duży dysonans pomiędzy atrakcyjnością i tempem tego, co robi w swoim czasie wolnym, a powolnością i jednostajnością tego, czym każą mu się zajmować $\mathrm{w}$ czasie nauki w szkole, $\mathrm{w}$ dodatku pozbawionej nierzadko możliwości korzystania z nowych technologii informacyjnych (Borawska-Kalbarczyk, 2015). Współczesna szkoła tworzy więc środowisko edukacyjne, niestety, tylko częściowo atrakcyjne i częściowo (lub wcale nie) pociągające uczniów intelektualnie, nie stwarzając tym samym zróżnicowanych możliwości emocjonalnego i poznawczego angażowania się w odkrywanie świata. Przekłada się to na słabą motywację uczniów do szkolnego wysiłku, gdyż edukacja jest daleka od ich codziennych zainteresowań. Skutkować to może powstaniem pewnych barier, trudnych do pokonania, jeśli nie zostaną w odpowiedni sposób przełamane.

Przedstawiony tutaj obraz szkoły potwierdzają wyniki dostępnych badań. W świetle projektu realizowanego przez Polskie Bractwo Kawalerów Gutenberga we współpracy z Instytutem Informacji Naukowej i Studiów Bibliologicznych Uniwersytetu Warszawskiego znaczna większość kadry nauczycielskiej deklaruje, że cyfrowe narzędzia powinny być wykorzystywane do nauki zarówno podczas lekcji, jak i w domu, chociaż wielu nauczycieli wolałoby, żeby technologie były wykorzystywane głównie poza szkołą (Jasiewicz, Batorski, Kisilowska, Mierzecka-Szczepańska, Luterek, 2013).

W efekcie badań przeprowadzonych przez Martę Wrońską zauważa się niską atrakcyjność zajęć medialnych oferowanych uczniom przez polskich nauczycieli pracujących w szkołach różnych szczebli, jak również ich niesamodzielność 
$\mathrm{w}$ funkcjonowaniu $\mathrm{w}$ wielowymiarowej przestrzeni cyfrowej. $\mathrm{W}$ toku badania elementów kultury medialnej, to znaczy w zakresie wiedzy o mediach, umiejętności stosowania mediów oraz postaw wobec mediów, okazało się, że nauczyciele sytuują się na niższym poziomie niż ich uczniowie, czego konsekwencją może być niechętny stosunek do włączania mediów cyfrowych w tok kształcenia. Marta Wrońska konkluduje:

nauczyciele, którzy mają medialnie edukować uczniów, posiadają spore braki w tym obszarze, w porównaniu ze swoimi wychowankami, mimo że w standardach kształcenia nauczycieli jest przepis dotyczący przygotowania nauczycieli do nabycia kompetencji w zakresie informacyjno-medialnym, a w grupie przedmiotów do realizacji jest technologia informacyjna. (Wrońska, 2015: 44)

Potwierdzają ten fakt wnioski płynące $\mathrm{z}$ „Międzynarodowego badania nauczania i uczenia się", z których wynika, że w Polsce tylko jedna trzecia nauczycieli często korzysta $\mathrm{z}$ technologii informacyjno-komunikacyjnych (Hernik, 2015), oraz analiza danych z „Międzynarodowego badania kompetencji komputerowych i informacyjnych". W świetle tych ostatnich wykorzystanie nowych mediów przez nauczycieli w Polsce na tle innych krajów lokuje się na poziome niskim - w polskich gimnazjach tylko $41 \%$ nauczycieli (najniższy odsetek wśród badanych krajów) co najmniej raz w tygodniu wykorzystuje komputer do nauczania (np. w Australii odsetek ten wynosi 90\%, a w Rosji i Korei Południowej - 76\%) (Sijko, 2014).

Tymczasem, w świetle dokumentu „Kluczowe dane o kształceniu i innowacjach z zastosowaniem technologii informacyjno-komunikacyjnych w szkołach w Europie", zakłada się, że IC mają pozytywny wpływ na edukację, a korzyści płynące $\mathrm{z}$ zastosowania technologii informacyjnych wykraczają poza samo stosowanie komputerów i Internetu, uwzględniając inne technologie, jak kamery cyfrowe i telefony komórkowe, które mogą wspierać nauczanie i osobisty rozwój uczniów. Większość państw europejskich wymienianych w raporcie zaleca używanie przez nauczycieli różnego rodzaju sprzętu: komputerów, projektorów lub rzutników, DVD, wideo, telewizji, kamer, tablic i wirtualnych środowisk dydaktycznych, które obejmują infrastrukturę ICT, co umożliwia tworzenie spersonalizowanej internetowej przestrzeni dydaktycznej (Kluczowe dane o kształceniu..., 2011). Innym przykładem są edukacyjne działania Austrian Institute for Applied Telecommunication (OIAT): w opracowanym poradniku przedstawia nauczycielom i rodzicom sposoby pokonywania zagrożeń związanych z komórkami, a także wskazuje szanse ich pozytywnego użycia (Korzystanie z telefonu komórkowego..., 2013).

Eksperci alarmują, że polskie szkoły są nadal niedoinwestowane, a znajdujący się w nich sprzęt informatyczny wymaga ciągłej modernizacji. Z obserwacji bada- 
czy wynika, że mobilnych urządzeń cyfrowych właściwie nie posiadają, a uczniom zabrania się używania własnego sprzętu. Laptopy są rzadkością zarówno w obecnym wyposażeniu, jak i w planach zakupowych. Stacjonarne komputery szkolne w zdecydowanej większości nie są multimedialne, ich konfiguracja najczęściej utrudnia lub uniemożliwia instalowanie i korzystanie z niestandardowego oprogramowania (Hojnacki, 2013: 46).

Tymczasem młodzi ludzie, dorastający w cyfrowym świecie, „chcą, aby nauczanie przystawało do rzeczywistego świata (...), chcą, żeby nauka była ciekawa, była dobrą zabawą" (Tapscott, 2010: 255), a w rzeczywistości obserwuje się głęboki rozziew między potrzebami uczniów a pozorowanymi działaniami dydaktycznymi nauczycieli w sferze medialnej. Przepaść między tym, jak uczniowie (z pokolenia sieci) myślą, a jak nauczają nauczyciele, uwidacznia się najwyraźniej w odniesieniu do spojrzenia na oferowane przez edukację metody kształcenia. Jak twierdzi Don Tapscott (a są powody, by uznać, że nie dotyka to jedynie amerykańskiego systemu oświaty), pokolenie współczesnej młodzieży nie zadowoli się biernym uczestnictwem i wysłuchiwaniem wykładów wygłaszanych przez nauczycieli (Tapscott, 2010: 225). Pozbawiony złudzeń co do jakości obraz edukacji, ale jakże prawdziwy zarysowuje Aleksander Nalaskowski. Pisze on, iż

edukację czynią ci, którzy językiem współczesnym kultury posługują się jako obcym, nabytym późno, pogardzanym (...). Jej odbiorcami, przymuszonymi do tej rytualnej konsumpcji uczestnikami, są młodzi, którzy z najwyższym trudem opanowują język wykładowy, czyli starą kulturę (...). Symboliczny nauczyciel ukorzeniony w świecie minionym przedstawia obraz świata współczesnego, którego nie traktuje ani serio, ani jako swój. (Nalaskowski, 2009: 64-65)

Nadzieją na niwelację zarysowanej tu technologicznej luki, zwłaszcza w sferze mentalnej, jest transformacja postaw nauczycieli, gdyż zdaniem Stanisława Dylaka

wielkim wyzwaniem dla szkoły jest właśnie stwarzanie uczniom okazji do podejmowania zadań szkolnych w przyjaznym im środowisku cyfrowym, a mądrego korzystania z tegoż można się skutecznie nauczyć tylko przez mądrze kierowane praktykowanie. (Dylak, 2013: 67)

W podobnym duchu formułuje uwagę Don Tapscott, pisząc

skoncentrujcie się na zmianach w metodach nauczania, a nie na rozwiązaniach technicznych. Nauka polega na radykalnej zmianie stosunków między nauczycielem a uczniami w procesie nauczania. Zrozumcie to dobrze i używajcie technologii do stworzenia takich warunków nauki, w których na pierwszym miejscu stawia się ucznia, dopasowuje się metody nauczania do jego potrzeb i pozwala na podejmowanie współpracy. (Tapscott, 2010: 258) 


\section{Zakończenie: dydakłyka epoki cyfrowej - wybrane egzemplifikacje}

Podsumowując wcześniejsze rozważania, należy stwierdzić, że współczesne pokolenie jest „stale podłączone”, żyjąc w schemacie 24/7/52/12, za pośrednictwem mobilnych urządzeń, które mają ze sobą wszędzie. Maciej M. Sysło trafnie zauważa, że „uczniów nie można odłączyć, bo połączenie jest nie tylko medium, a stanem świadomości” (Sysło, 2014b). Oczywiście te narzędzia muszą być stosowane także w edukacji, która nie może walczyć z digitalizacją młodzieży. Jest to proces nieuchronny, postępujący, rozwijający się w nieznanym kierunku, który nauczyciele powinni dostrzec i zaakceptować, a następnie włączyć w nurt własnych dydaktycznych oddziaływań, aby wzmocnić edukacyjną atrakcyjność procesu kształcenia, a przede wszystkim wychowywać uczniów do mądrego i rozsądnego korzystania z mediów.

Umiejętne włączenie w nurt edukacyjny nowych technologii może przyczynić się do stworzenia przyjaznego dla ucznia, zróżnicowanego środowiska uczenia się, których kilka, wybranych egzemplifikacji wskazanych będzie poniżej.

Wykorzystywanie technologii cyfrowych w edukacji uruchamia wiele pozytywnych płaszczyzn oddziaływania na ucznia. Jedną z nich jest wspieranie kreatywności i innowacyjności. Portal Innowacji, prowadzony przez Polską Agencję Rozwoju Przedsiębiorczości w ramach Narodowego Programu Przedsiębiorczości, uznał, że ostatecznym celem innowacyjności edukacyjnej jest angażowanie młodego człowieka w świat innowacyjnych technologii, przygotowywanie i motywowanie do walki konkurencyjnej na rynku pracy w kontekście zglobalizowanego świata. Szczegółowa lista działań określonych jako innowacyjne obejmuje między innymi: edukację uczestniczącą, multimedialne prezentacje edukacyjne, gry edukacyjne, „mobilną szkołę”, wprowadzenie „najnowocześniejszych technologii do nauczania”, „spersonalizowany Internet” w nauczaniu (Konopczyński, 2014). Nauczanie wspomagane komputerowo nie osądza i motywuje, umożliwia częste i szybkie przekazywanie informacji zwrotnej, indywidualizuje proces uczenia się poprzez dostosowanie do potrzeb uczniów, pozwala uczniom na większą samodzielność, zapewnia multisensoryczne środowisko uczenia się (obrazy, dźwięki i symbole) (Pitler, Hubbell, Kuhn, 2015). Jedną z dróg wzmocnienia tradycyjnych strategii dydaktycznych z wykorzystaniem technologicznego zaplecza zasobów ucznia i jego umiejętności jest aktywowanie mobilnej edukacji, omówione w raporcie „Kierunki rozwoju edukacji wspieranej technologią. Nowe technologie w edukacji. Propozycja strategii i planu działania na lata 2014-2020" (Sysło, 2014a). Jej składowymi są urządzenia mobilne, dostęp do Internetu, wirtualne środowisko kształcenia i dostosowania organizacyjne. 
Jak czytamy w raporcie, warunkiem tego, aby

mobilne urządzenia mogły stanowić pomoc dydaktyczną, powinny być częścią rozwiązania, które określamy mianem edukacyjnej technologii mobilnej (...), która służy do realizacji kształcenia mobilnego, czyli takiego, które może przebiegać w dowolnym czasie i w dowolnym miejscu, w którym uczniowie i nauczyciele chcieliby kontynuować kształcenie. (Sysło, 2014a: 11)

Wykorzystanie mobilnych technologii cyfrowych w procesie kształcenia redefiniuje znany wszystkim proces kształcenia w kierunku nowej kultury uczenia się, dzięki której:

- następuje przeniesienie nacisku z nauczania na uczenie się (przejście od modelu teacher centered do learner centered);

- możliwa jest personalizacja, przejawiającą się możliwością tworzenia indywidualnych środowisk i ścieżek kształcenia;

- przyczynia się do realizacji idei learning anytime i anywhere, czyli uczenia się w dowolnym czasie i miejscu;

- uczący się gromadzi swoje indywidualne zasoby w osobistym archiwum i może tworzyć na ich podstawie e-portfolia, będące materiałem do refleksji nad własnym kształceniem i rozwojem oraz współczesną wersją wizytówki uczącego się;

- proces kształcenia może mieć charakter asynchroniczny (nie wszyscy uczą się jednocześnie tego samego) i rozproszony (przebiega w różnych miejscach i w różnym czasie);

- system kształcenia jest oparty na ideach konstruktywistycznych, czyli budowania i rozwoju wiedzy przez uczniów w rzeczywistym środowisku ich przebywania i rozwoju (Sysło, 2014a: 12).

$\mathrm{W}$ aspekcie tematu podjętego w niniejszym artykule niezwykle ważna staje się opinia wypowiedziana przez Heliodora Muszyńskiego, który, zauważając nieadekwatność współczesnego modelu edukacji do warunków, w jakich instytucja ta się znalazła, stwierdza:

Dla szkoły oznacza to konieczność stanięcia wobec alternatywy, której nie da się ani zlekceważyć, ani ominąć: albo szkoła wyjdzie tym zmianom naprzeciw i dostosuje swoją działalność do warunków życia oraz funkcjonowania w społeczeństwie medialnym, albo stanie się instytucją o coraz mniejszym znaczeniu w zapewnianiu kulturowej ciągłości życia społecznego, ale także rozwoju i postępu społecznego. Zarazem przestanie być instytucją ułatwiającą dorastającym jednostkom bezkolizyjne uczestnictwo społeczne, osobisty rozwój i pomyślną samorealizację. (Muszyński, 2011-2012: 44) 
Nie sposób sobie wyobrazić zatem współczesnej szkoły niewykorzystującej nowoczesnych rozwiązań technologicznych, ale w tym miejscu należy mieć na względzie, że każde narzędzie może być zarówno użyte, jak i nadużyte. Działania nauczycieli włączających media cyfrowe w proces kształcenia muszą się więc ogniskować na tym, by minimalizować „możliwość nadużyć i maksymalizować korzyści płynące z racjonalnego i odpowiedzialnego wykorzystywania narzędzi” (Morbitzer, 2010: 8). Zapewnienie wielu możliwości kontaktu z cyfrowymi narzędziami i dostarczenie młodym ludziom bodźców i inspiracji ze strony nauczycieli w roli cyfrowych przewodników wychodzi naprzeciw przeciwdziałaniu indolencji szkoły w sferze wykorzystania nowych mediów i pozwala mieć nadzieję, że w rezultacie podjętych działań zostaną ukształtowane pożądane postawy uczniów, sprzyjające prawidłowemu funkcjonowaniu w wielowymiarowej przestrzeni cyfrowej.

\section{Literatura}

Bard A., Söderqvist J. (2008). Netokracja. Nowa elita władzy i życie po kapitalizmie. Warszawa.

Borawska-Kalbarczyk K. (2015). Kompetencje informacyjne uczniów w perspektywie zmian szkolnego środowiska uczenia się. Warszawa.

Cantelmi T. (2015). Technopłynność. Człowiek w epoce internetu: technopłynny umysł. Kraków.

Digital in 2016 (2016). http://wearesocial.com/uk/special-reports/digital-in-2016, dostęp 12.01.2017. Dylak S. (2013). Architektura wiedzy w szkole. Warszawa.

Eriksen T.H. (2003). Tyrania chwili. Szybko i wolno płynący czas w erze informacji. Warszawa.

Filiciak M., Danielewicz M., Halawa M., Mazurek P., Nowotny A. (2010). Młodzi i media. Nowe media a uczestnictwo w kulturze. Raport Centrum Badań nad Kulturą Popularną. Warszawa.

Gleick J. (2003). Szybciej. Przyspieszenie niemal wszystkiego. Poznań.

Gleick J. (2012). Informacja, bit, wszechświat, rewolucja. Kraków.

Goban-Klas T. (2002). Edukacja wobec pokolenia SMS-u. [W:] W. Strykowski, W. Skrzydlewski (red.). Media i edukacja $w$ dobie integracji. Poznań.

Goban-Klas T. (2005). Społeczeństwo masowe, informacyjne, sieciowe czy medialne? „Ethos” nr 1-2 (69-70), s. 100-114.

Hejwosz-Gromkowska D. (2015). Młodzież, Facebook a problem partycypacji społecznej. „Studia Edukacyjne" nr 35, s. 179-188.

Hernik K. (red.). (2015). Polscy nauczyciele i dyrektorzy w Międzynarodowym badaniu nauczania i uczenia się TALIS 2013. Warszawa.

Hojnacki L. (2013). Cyfrowych tubylców trzeba uczyć inaczej. Dlaczego i jak - wprowadzenie. [W:] P. Plichta, J. Pyżalski (red.). Wychowanie i kształcenie w erze cyfrowej. Łódź.

Jasiewicz J., Batorski D., Kisilowska M., Mierzecka-Szczepańska A., Luterek M. (2013), Kompetencje cyfrowe nauczycieli i wykorzystanie nowych mediów w szkolnictwie podstawowym, gimnazjalnym i ponadgimnazjalnym - diagnoza, http://pobierzwiedze.pl/wp-content/uploads/2013/11/Nowe-media-w-polskiej-szkole-wyniki-bada\%C5\%84.pdf, dostęp: 14.03.2016. 
Jaskuła S. (2015). Pedagogika przestrzeni informacyjnej. [W:] M. Tanaś, S. Galanciak (red.). Cyberprzestrzeń, człowiek, edukacja. Cyfrowa przestrzeń kształcenia. Kraków.

Kerckhove D. de (1996). Powłoka kultury. Odkrywanie nowej elektronicznej rzeczywistości. Warszawa. Kluczowe dane o kształceniu i innowacjach $z$ zastosowaniem technologii informacyjno-komunikacyj$n y c h$ w szkołach $w$ Europie (2011). Fundacja Rozwoju Systemu Edukacji.

Klus-Stańska D. (2005). Rzecz o ryzyku kulturowej nieadekwatności edukacji szkolnej. „Forum Oświatowe" nr 1, s. 23-46.

Konopczyński F. (2014). Komentarz: Edukacja dla innowacyjnej gospodarki. Studium Polskie. http:// kalecki.org/komentarz-edukacja-dla-innowacyjnej-gospodarki-w-polsce, dostęp: 12.01.2017.

Krauze-Sikorska H., Klichowski M. (2013). Świat digital natives, Młodzież w poszukiwaniu siebie i innych. Poznań.

Ledzińska M. (2009). Człowiek współczesny w obliczu stresu informacyjnego. Warszawa.

Lister M., Dovey J., Giddings S., Grant I., Kelly K. (2009). Nowe media. Kraków.

Mead M. (2000). Kultura i tożsamość. Studium dystansu międzypokoleniowego. Warszawa.

Melosik Z. (2013). Facebook i społeczne konstrukcje narcyzmu (o tożsamości zamkniętej w celi wizerunku). „Studia Edukacyjne” nr 26, s. 99-118.

Morbitzer J. (2010). Szkoła w pułapce Internetu. http://www.up.krakow.pl/ktime/ref2010/morbitz. pdf, dostęp: 23.03.2012.

Muszyński H. (2011-2012), Nauczyciel w świecie medialnym, „Neodidagmata” nr 33-34, s. 39-47.

Nalaskowski A. (2009). Edukacja w otoczeniu burzliwym, czyli jaka burza, taka edukacja. [W:] Z. Kwieciński, R. Borowicz (red.). Wychowanie w społeczeństwie permanentnego kryzysu. Torun.

Ostrowicki M. (2007). Człowiek w rzeczywistości elektronicznego realis. Zanurzenie. [W:] K. Wilkoszewska (red.). Wielka Księga Estetyki w Polsce. Kraków.

Pitler H., Hubbell E.R., Kuhn M. (2015). Efektywne wykorzystanie nowych technologii na lekcjach. Warszawa.

Prensky M. (2012). From Digital Natives to Digital Wisdom. Hopeful Essays for 21st Century Learning. London.

Przybyła M. (2012). Digital natives vs. digital immigrants? - szkoła a kreatywność on-line. „Studia Edukacyjne" nr 23, s. 203-216.

Sijko K. (2014). Kompetencje komputerowe i informacyjne młodzieży w Polsce. Raport z Międzynarodowego badania kompetencji komputerowych i informacyjnych ICILS 2013. Warszawa.

Sysło M.M. (2014a). Kierunki rozwoju edukacji wspieranej technologia. Nowe technologie w edukacji. Propozycja strategii i planu działania na lata 2014-2020. Wrocław, Toruń, Warszawa.

Sysło M.M. (2014b). Wykorzystanie nowoczesnych technologii w edukacji uczniów zdolnych ze szczególnym zwróceniem uwagi na potrzeby uczniów o specjalnych potrzebach edukacyjnych, https:// www.ore.edu.pl/wp-content/plugins/download-attachments/includes/download.php?id=4984, dostęp: 15.01.2017.

Szlendak T. (2009). Co się dzieje z czasem wolnym? Od codziennego znoju i odpoczynku do codzienności, w której czas eksplodowat. [W:] M. Bogunia-Borowska (red.). Barwy codzienności. Analiza socjologiczna. Warszawa.

Szpunar M. (2016), Kultura cyfrowego narcyzmu. Kraków.

Tapscott D. (2010). Cyfrowa dorosłość. Jak pokolenie sieci zmienia nasz świat. Warszawa.

Wrońska M. (2015). Edukacja szkolna a kultura medialna adolescentów. [W:] R. Czerski, R. Wawer (red.). Nowoczesne media w przestrzeniach edukacyjnych. Lublin.

Zając A. (2011). Uczenie się w sieci przez zapping, „Neodidagmata” nr 31/32, s. 109-126. 